\title{
Volcanic Hazard Communication at Pinatubo from 1991 to 2015
}

\author{
Chris Newhall $₫$ and Renato U. Solidum
}

\begin{abstract}
When Pinatubo re-awakened in early 1991, very few people within the vicinity were familiar with volcanic hazards, and even fewer believed that Pinatubo could impact them. Scientists knew more, but were still struggling to answer:
\end{abstract}

- How often and how explosively did Pinatubo erupt, and when was its most recent eruption?

- What precursors could be expected in advance of a very large (VEI $\geq 6$ ) explosive eruption?

- What was happening beneath Pinatubo that was driving 1991 unrest?

To reach an exceptionally diverse audience and to counter widespread scepticism, scientists tried a whole package of communication measures, including simplified alert levels; a "worst case" hazard map; a probability tree; personalized briefings for local and national government officials, military and civil defense officials, nuns, and the news media; use of a IAVCEI video on volcanic hazards on broadcast TV and in briefings; volcanology tutorials for school teachers; talks on the mountain with villagers and anti-government guerrillas; and beer and hotdogs too. Forecasts were just-in-time and generally correct about what areas would be at risk. Overall, pre-eruption communication achieved its goal of getting people out of harm's way. Three lessons stand out: use simple, multipronged communications, especially video; include worst case scenarios in your warnings, together with estimated probabilities thereof; and be willing, as scientists

C. Newhall $(\bowtie)$

Mirisbiris Garden and Nature Center, Santo

Domingo, Albay, Philippines

e-mail: cgnewhall@gmail.com

R.U. Solidum

Philippine Institute of Volcanology and Seismology

(PHIVOLCS), Quezon City, Philippines 
and decision makers, to recommend evacuations even if uncertainty is still high and there is still a chance of false alarm. For more than a decade after the 1991 eruption, rain-induced lahars threatened even more people and more infrastructure than the eruption itself. Several groups of scientists and engineers worked on the lahar threat, each coming up with slightly different long-term assessments that appeared to the public as bickering or incompetence. Scientists' credibility was seriously diminished. Decisions of what lahar-mitigation projects to build - including a succession of inadequate ones-were influenced less by science and more by public pressure, pragmatism, back-room politics, and profit. Short-term or immediate lahar warnings were communicated by scientists and by police-manned watch points. The scientific warnings were technically superior but the police warnings had greater credibility, as they were from familiar sources and easily understood. Communication of hazard information at Pinatubo saved many lives, and we are proud and privileged to have been part of preventing a much worse disaster. However, margins of safety were narrow and some deaths that did occur could have been prevented by better communication.

\section{Introduction}

The 1991-92 eruptions of Mount Pinatubo, Philippines, would affect a population in Central Luzon that was unfamiliar with and initially sceptical about volcanic hazards. That population was exceptionally diverse, including indigenous Aeta people on the volcano itself, helped by trusted nuns and pastors, and sharing the volcano with a small but influential band of guerrillas of the New Peoples' Army. Around the volcano were nearly a million lowland Filipinos in several large cities and towns of three provinces, and two large American military bases that were more like America than the Philippines. And in the skies above and around Pinatubo, commercial as well as military aviation had to be alerted.

Following small phreatic explosions on April 2, 1991, a team of Filipino and American scientists were trying urgently to decipher the history of the volcano and the unrest. What little we knew of Pinatubo's geologic history indicated that a major explosive eruption was possible, and geophysical and geochemical monitoring-just started-was indicating continuing but (as-yet) not escalating unrest. It was not clear that the volcano WOULD erupt, but it was clear that IF IT DID, the eruption was likely to be large and explosive.

Facing strong scepticism from officials and the public unfamiliar with volcanic threats, and with no indication of how much time remained before an eruption could occur, we had to quickly find ways to teach about volcanoes and overcome that scepticism. If unrest escalated, officials would have to be convinced to evacuate large numbers of people to safety. Unrest did escalate, and most of those at high risk were successfully evacuated.

After the large eruption of June 15, 1991, focus shifted to the hazard of rain- (and lake-) related lahars. Though there was more time for a lahar information campaign, the long ( $>10$ year) duration complicated the effort. Again, large numbers of people were at risk, and nearly all were moved to safety.

Although communications and mitigation were broadly successful, we stress that the successes were often "just in time" and "just barely enough." Most of the deaths that did occur could have been prevented, and many more deaths could have occurred had the eruption or the lahars been slightly sooner or larger. We tell this 
story in the hope that it will help colleagues in similar situations in the future add margins of safety.

\section{Audiences: Who Needed to Learn About Volcanic and Lahar Hazard?}

Audiences for our hazard communications were primarily decision-makers, community opinion leaders, and the news media. They in turn conveyed hazard messages and suggested actions to the public. Given that the total population at risk was roughly 1 million, the task was large and messages would need to be disseminated through many levels and in many ways. Scientists communicated directly with hundreds of officials at various levels, and they in turn reached out to the million.

In the Philippines, there is a well-established hierarchy of government and NGO bodies charged with disaster risk mitigation. At the top is the National Disaster Risk Reduction and Management Council (NDRRMC), known at that time as the National Disaster Coordinating Council, (NDCC), which includes top civilian, military, NGO officials, and scientists. The executive arm of the NDRRMC is the national Office of Civil Defense (OCD), led at the time by Engineer Fortunato Dejoras. Similar crisis coordinating functions are replicated at the regional (RDRRMC), provincial (PDRRMC), city or municipal (MDRRMC), and barangay (village) level, and execution is by local offices of OCD and corresponding offices of other government agencies and NGOs. Needs are assessed from the bottom or middle up; decisions are made mostly at the regional or provincial level, or higher if necessary, and passed down to local levels. In the case of volcanic hazards, assessments and recommendations are made by the Director of the Philippine Institute of Volcanology and Seismology (PHIVOLCS), or his/her designated representative.

At and around Pinatubo, virtually no one in this hierarchy had experience with volcanic hazards, so all needed urgent education. The sole exceptions were geoscientists from PHIVOLCS, joined by colleagues from the US Geological Survey (USGS) and a few university-based geoscientists.

News media had perhaps slightly more experience with volcanic hazards, but not much. There are relatively few science reporters in the Philippines, and some of the best reporters turned out to be generalist regional reporters who familiarized themselves with the issues better than national reporters who were pulled in many more directions.

Before the climactic eruption of June 15, 1991, nearly all communications with the preceding groups were led by the late Dr. Raymundo Punongbayan, then-director of PHIVOLCS. Ray was a talented communicator who quickly earned the trust of those he briefed. Briefings were held for the NDCC (in a meeting led by then-Defense Secretary and later President Fidel Ramos), for the Governors and staff of the three provinces that adjoin at the summit of Pinatubo (Zambales, Pampanga, and Tarlac), and for the Mayor of Angeles City. The Mayor of Olongapo City had the benefit of personal advice from several university-based scientists, including Dr. Kelvin Rodolfo and a young PHIVOLCS scientist, here the 2nd author. Other mayors joined the provincial level meetings. Dr. Punongbayan also developed a good rapport with news media, and he tapped them to help disseminate information. Other PHIVOLCS and USGS scientists were largely free to concentrate on field work and data interpretation, undistracted by media because Dr. Punongbayan handled their requests.

The American military bases were self-contained, with their own command structure, logistics, hospital, schools, businesses, and the like. Although the primary mission of the USGS scientists was to work with long-time PHIVOLCS colleagues in support of the PHIVOLCS mission, the USGS scientists were also granted access to logistical resources of the US military and, in return, kept the US military informed of developments in parallel with communications to the NDCC. Because the US Air Force was preparing a contingency plan in case evacuation became 
necessary, it sought scientific advice not only for commanders but also for enlisted personnel on whom base operations depended, for teachers, and for hospital staff. An initial attempt to also teach schoolchildren about the hazard had to be abandoned-for lack of time-in favour of a single-day briefing for all science teachers of Clark Air Base.

\section{Pre-eruption Messages}

One might liken the scientific effort-and the communication effort - to running a race against an unknown competitor, Pinatubo. At the time of the first phreatic explosions on April 2, 1991, no instruments monitored the volcano and there were no background data of monitoring. Fortunately, there was some prior geologic knowledge of Pinatubo, from a site safety study for a nearby nuclear power plant and from exploration for geothermal power, which told of what HAD happened before and COULD happen again, but what officials wanted was information about what WOULD happen. Furthermore, even worldwide, there was no information about the expectable precursors of a VEI 6 eruption, which we could see from the geology was a strong possibility.

Scientists, by training, are conservative in what they say. Data must be ample and convincing, and uncertainties should be low before a paper is published or advice is given. However, that conservatism must sometimes be overridden in times of volcanic crises.

In chronologic order, pre-eruption messages evolved through the following sequence:

- Pinatubo is a volcano, and is restless, so here is a primer on volcanic hazards (April-May).

- Near the volcano, the only way to protect yourself is to evacuate before an eruption. We may recommend evacuations from within 10 , 15, $20 \mathrm{~km}$ radius (later, adding 30 and $40 \mathrm{~km}$ radius). (With radii adjusted for each specific volcano, this is a standard PHIVOLCS message in the face of any volcanic crisis) (April-June).
- We are not yet sure whether Pinatubo WILL erupt, but if it does, the eruption will be big and bad (late April).

- Evidence (as of May 13) shows that rising magma is causing the unrest.

- Even though this volcano is new to us too, we will try to raise alerts progressively if an eruption is approaching, giving you days up to two weeks of advance warning and, later, final notice hours or a day before an eruption (May 13).

- In return, we ask you (officials and the public) to understand that there might be a false alarm or two along the way. Please bear with us.

- Many areas have been swept by lethal volcanic flows in the past, or affected by ashfall, and could be similarly affected by a new eruption (hazard map, May 23).

- The volcano MAY erupt within 2 weeks (June 5).

- The volcano MAY erupt within $24 \mathrm{~h}$ (June 7). All within a $20 \mathrm{~km}$ radius of the summit should evacuate.

- The volcano has started to erupt, though only with a lava dome (June 7).

- The volcano has started explosive eruptions (June 9).

- Even though what you saw yesterday and today was impressive, the big one is still to come (June 12, 13, 14). On June 14, all those within $30 \mathrm{~km}$ radius of the summit should evacuate.

- A typhoon will arrive on June 15 (message from the weather bureau PAGASA).

- A massive eruption is in progress (June 15). Those within $40 \mathrm{~km}$ radius of the summit should evacuate, a recommendation easier made than followed.

Our message about possible false alarms was given in briefings to Governors and other decision-makers. Volcanologists have been notably averse to false alarms ever since the 1976 crisis at Soufrière Guadeloupe (Fiske 1984) and initially, we worried about this at Pinatubo as well. But we were reassured in our briefing in Zambales province when one of the attendees, a nun working with indigenous Aetas, told us they 
would happily accept premature warnings. They were more concerned that warnings might be too late. Not all would have been so forgiving, but we took the nun's words to heart. Social science research on earthquake and weather hazards recognizes some so-called "cry-wolf" reduction in scientific credibility (e.g., Atwood and Major 1998), but less than often presumed (Dow and Cutter 1998; Barnes et al. 2007 and references therein).

One communication that was, in retrospect, underemphasized, warned of ash in areas far from the volcano. Although warning was technically made, it was not emphasized sufficiently, especially in light of the typhoon rain that almost doubled the weight of ash on roofs and led to most of the eruption-related deaths. Another result of this under-emphasis was failure to warn aircraft outside the Philippine Flight Information Region (FIR), mostly over Indochina. We thought we had the aviation hazard covered through the Philippine FIR, and didn't even think of FIR's beyond the Philippines.

Additional details of eruption warnings, including dates and text of alert levels and recommendations for evacuation radii, may be found in Punongbayan et al. (1996) and Tayag et al. (1996).

\section{How Were the Warnings Prepared and Presented?}

\subsection{Briefings and Video}

By mid-May, as soon as we were reasonably sure that magma was rising and we had drafts of warning materials, the Office of Civil Defense arranged for the Director of PHIVOLCS (Dr. Punongbayan) to brief the Governors of each affected province (Pampanga, Zambales, and Tarlac), and the Mayor of Angeles City. The Governors, in turn, arranged for attendance of town mayors, captains of barangays closest to the volcano, and representatives of NGOs and news media. The general format of each meeting included an introduction by the Governor or Vice-Governor, followed by presentation of what scientists knew about Pinatubo in general and about the hazard facing each province, and showing and discussion of a rough cut of the IAVCEI video "Understanding Volcanic Hazards" prepared by Maurice Krafft and others. Finally, there would be open discussion of general mitigation steps, though most discussion of specific mitigation steps came after these briefings. In most of these briefings, attention levels were high and many good questions were asked; in only one, that for the Mayor of Angeles City, was there official disinterest or hostility.

The IAVCEI video deserves special mention. Shortly after the terrible mudflow (lahar) disaster at Nevado del Ruiz Volcano (Colombia) in 1985, volcanologists agonized over how to prevent such disasters in the future. Because people of Armero and other towns at risk seemed not to have understood the seriousness of warnings they received, they did not walk to safety even though they could have done so. Apparently, they did not understand that a "flujo de lodo" (literally, a flow of mud) could in fact be a huge wall of mud, sand, boulders, trees, and more. Accordingly, Maurice Krafft and others set out to make a video that showed, in starkly graphic ways, the nature of each volcanic hazard, how far and fast it travels, and what it does when it hits houses and people. The ad-hoc steering committee for this video debated whether to include dead bodieslest audiences find it too hard to watch - but in the end decided for inclusion to shock audiences into attention. Pinatubo was the next big event to threaten a population unfamiliar with volcanic hazards and, fortunately, scientists had by then a rough cut of Maurice's video, sufficient for public screening. This video was highly effective. Many who simply hadn't grasped the threat before seeing this video became converts soon after. The old saying, "A picture is worth 1000 words" might be re-written to say a "A video is worth 1,000,000 words!” Interestingly, we found no great revulsion from scenes of dead bodiesperhaps TV programming had already made this an everyday sight. But a short clip of a young girl trapped and shivering in the Armero lahar deposit drew audible gasps of horror in every briefing. It was VERY effective. 
Unaware yet of its powerful reception at Pinatubo, Maurice Krafft and his wife Katia were dissatisfied with the video's footage of pyroclastic flows (much better footage is available now), so enroute to Pinatubo they stopped at Unzen to get better footage. They misjudged the threat and were themselves killed by a pyroclastic flow. That sad irony further increased the impact of the video as it was shown at Pinatubo.

Although technically the video was copyrighted by IAVCEI, we decided in the interest of time and the spirit in which the video was made to show it on broadcast TV and to distribute copies freely at each briefing. No doubt many copies of copies were also made. Today, one might post a video on YouTube; at that time, none of today's social media were available. Readers of this paper wishing to order a re-mastered DVD of this video, and a sequel, may order it at http://www.volcanovideo.com/ p1IAVCEI.html.

In addition to briefings at the provincial level, Dr. Punongbayan also gave briefings to key national leaders. In one, he briefed then-President Corazon Aquino. In another, led by then-Secretary of National Defense Fidel Ramos and held at Camp Aguinaldo, he briefed assembled Cabinet members and other key officials. We recall a multi-tasking, busy Gen. Ramos calling a timeout after this briefing, and remarking to Dr. Punongbayan that he heard the message loud and clear, and half-joked that the Philippine government had better hurry up the renegotiation of the RP-US military bases agreement before there was nothing left to negotiate about.

While Dr. Punongbayan handled briefings at the national and provincial levels and for the media, several other members of the joint PHIVOLCS-USGS team provided briefings at lower levels. One PHIVOLCS team was based in villages on the NW flank of Pinatubo and quickly developed trust and provided information on the hazard. Field parties often encountered and stopped to talk with other villagers. One time, a group approached our helicopter while we were installing a seismic station. Other times, we stopped in roadside villages on our way to study outcrops, and the requisite courtesy call on a village captain would inevitably and fruitfully turn into quite a long discussion. In one village, we met with both indigenous Aetas and rebel guerrillas of the New People's Army. In another village from which the volcano could not even be seen, we didn't find the village captain so we spoke instead with his wife, who seemed not to understand at all, yet we know that residents of this village did ultimately evacuate to safety. These encounters and outreach were by no means comprehensive. A few PHIVOLCS scientists started systematic outreach in towns around the foot of the volcano, but owing to limits in time and transport, most of our outreach was bootlegged onto our field work.

Those of us on Clark Air Base at the East foot of Pinatubo also provided near-daily briefings for military officers and officials from nearby towns. We spoke to several classes of schoolchildren but quickly realized that the only way we could reach larger numbers would be to teach the teachers, especially science teachers. Inside Clark Air Base, a session for science teachers was quickly arranged; outside the base, we connected with only a few teachers, far from all.

Also within Clark Air Base, we gave briefings to individual units including the hospital and, at the suggestion of the Deputy Base Commander, to a level of staff called "chief master sergeants." The "chiefs" were eminently practical - the real "doers" of the base. Our makeshift Pinatubo Volcano Observatory (PVO), in a crowded apartment for enlisted personnel, became a hub for curious and concerned daily visitors, including the base meteorologists, officers, and even their wives. On one occasion when activity ramped up, we summoned top officers of Clark and Subic to PVO. Their arrival by helicopter and thence in cars bearing the flags of admirals and generals drew quite a lot of attention and gossip throughout the base. Because we relied initially on the base weather office for access to a fax machine, US Air Force weathermen (and by extension, their superior officers) were also privy to fax communications between scientific team at Clark and Director Punongbayan in Manila. One fax from Director Punongbayan, about alert 
levels if we recall, arrived at PVO with yellow highlights! Even though the Base Commander wanted to keep our work quiet, there was really no way to do so, and occasional breaches were actually quite useful! Finally, in late May, the US Air Force command realized it needed to run an interview with a scientist on the base TV station, but the interview was tightly scripted and the pre-scripted wrap-up by the interviewer was much more reassuring than the interview itself.

\subsection{Alert Levels}

We soon recognized that, given the large, diverse audience and widespread unfamiliarity with the threat, all of our warnings would need to be very simple. One such simplification was definition of numbered alert levels from 0 (no unrest) to 5 (large explosive eruption in progress) (for details, see Punongbayan et al. 1996; Tayag et al. 1996). These were patterned, from vague and stressed memory, on alert levels first introduced at Rabaul (Papua New Guinea) and later adapted for eruptions in Alaska (USA) (see brief histories of alert levels in Fearnley et al. 2012; Fearnley 2013; Winson et al. 2014). Levels 3 and 4 of the Pinatubo scheme anticipated forecast time windows (2 weeks and $24 \mathrm{~h}$ ) within which an eruption might occur, and each level had an interpretation of activity. We intended that Civil Defense could design and key their mitigation actions to these alert levels. Probably, they would have done so had not events developed so rapidly in early June that -in effect-recommended evacuation radii from the Director of PHIVOLCS pre-empted plans that Civil Defense was still preparing. In recent years there has been much re-examination of alert schemes and debate of whether they should include forecasts and formal linkage to responses, making scientists de-facto decision makers. Given the extreme urgency at Pinatubo, we think both the forecast and the de-facto decision-making role of PHIVOLCS were necessary, though we acknowledge that these matters should be discussed and agreed elsewhere on a country-by-country basis.
PHIVOLCS and civil defense leaders still link alert levels and responses, but in recognition of uncertainties and differences between volcanoes, PHIVOLCS has made the forecast windows less precise.

The general upward progression of levels resembled a familiar 3-level alert used for typhoons in the Philippines, but had the opposite sense to a countdown of alerts used by the US military. Fortunately, the US military agreed to use our scheme rather than their own.

We did note one misunderstanding of the wording on the alert levels. For alert levels 3 and 4 , the wording stated that "an eruption was possible within (a specified timeframe, 2 weeks or 24 h)." Strictly speaking, we meant that we could no longer guarantee that an eruption would not occur within that period; however, the simpler reading of "could occur within that timeframe" would have been an acceptable simplification. In Pilipino, that would have been stated as "ma-aaring mangyari sa loob ng (dalawang lingo o 24 oras)." Perhaps since we wrote it only in English, many misread it to mean that "an eruption WILL occur within 2 weeks or $24 \mathrm{~h}$ " or, worse yet, "an eruption WILL occur in exactly 2 weeks or 24 h." If differences between the terms "could occur" versus "will occur", and between "in" versus "within" might be misunderstood, use the local language to clarify! No serious harm was done, as those making final evacuation recommendations understood the terms as intended.

Our alert level scheme also included guidance for step down, with built-in delays to guard against premature lowering of alert levels. We think such guidance for step-downs is helpful, partly to guard against sudden decreases in activity that are "calm before the storm," and partly to allow orderly stepdown, without embarrassment, should unrest truly stop. Many magma intrusions fail to reach the surface and moveable alert levels (up and down) are designed as an alternative to forecasts that may prove wrong. In the case of Pinatubo, we didn't have occasion to use the stepdown until well after the climactic eruption. 


\subsection{Pre-eruption Hazard Map}

Hazard maps are the geoscientist's standard response to the question, "What areas are at risk?" Our pre-eruption map was based mainly on quick reconnaissance of the maximum extent of pyroclastic flows from past eruptions of Pinatubo. In most areas this was immediately obvious both on the ground and on aerial photos. Our geological team doing field work compared notes with Director Punongbayan who was interpreting aerial photos from his office in Quezon City. In most cases, the field exposures (in canyon walls) extended slightly beyond the distinctive, dissected topography of old pyroclastic flows; in a few cases, e.g., near Barangay Pasbul, of Floridablanca town, suspect topography was found in aerial photos and later confirmed by ground visit. The aerial photos we had were well out of date, and we note with pleasure how much better it is to have modern satellite coverage with current roads and quarries.

We sketched the outline of prehistoric pyroclastic flows onto a single sheet of paper on which we had also traced main highways and towns. For safety, we added $0.5-1.0 \mathrm{~km}$ of buffer zone around the known pyroclastic flow extent. In our original sketch we showed that ash could fall anywhere on the area of the map; in a cleaned-up sketch, the most likely directions of ashfall were shown. Potential lahars were shown only as hash marks down the main river channels - a simplification that would be greatly expanded after the eruption. Without calling it as such, we intended this map to reflect our "worst-case" scenario, VEI 6 eruptions from Pinatubo. Fortunately, the actual reach of pyroclastic flows almost perfectly matched the hazard zones on our map, and did not reach as far as what we later discovered was the reach of an even larger prehistoric eruption. These sketched maps were shown, copied and distributed at all briefings after May 23 and also reproduced in one or more national newspapers.

In retrospect, we can see that our hazard map — while useful-was difficult for some audiences to understand. Many otherwise well-educated people are unable to read maps, and maps in standard plan view were an even more difficult abstraction for those less educated. Haynes et al. (2007) and Leone and Lesales (2009) offer excellent suggestions on how to make hazard maps more readily understandable, e.g., by use of $3 \mathrm{D}$ visualization.

\subsection{A Probability Tree}

Newhall and Hoblitt (2002) and Newhall and Pallister (2015) describe relatively simple ways to estimate probabilities of volcanic events and their consequences, and thereby help officials and those at risk to decide on what risks to take. At Mount St. Helens, calculations were carried all the way to annual risk of death, which allowed loggers and others to compare volcanic risk to more familiar occupational and lifestyle risks.

The first probability tree at Pinatubo (May 17) considered just one scenario, of pyroclastic flows to the East and onto Clark Air Base. We carefully did not exaggerate any hazard or risk, but we wanted to make sure that officials understood that hazards and risk were, in fact, unacceptably high. Our estimate of a $3 \%$ chance of pyroclastic flows reaching Clark and killing thousands within the coming months was immediately understood by US Air Force officers to be unacceptable. The Director of the national Office of Civil Defense, Engr. Dejoras, saw similarly unacceptable risk for the civilian population all around Pinatubo. Social science research has reaffirmed the pitfalls of using ambiguous adjectives like "high" or "low" to describe hazard and risk, and the advantages of quantifying those hazards (Doyle et al. 2014 and references therein). Once quantified, volcanic risk can be compared to more familiar risks and to levels of risk judged acceptable under the circumstances.

Public discussion of the probability tree at Pinatubo might have helped in our general education campaign, but probability is a difficult concept for many non-technical persons so for want of time we discussed it only with those who already understood probabilities. When we did discuss probabilities, we usually spoke in terms of "percent chance" or "odds" rather than strict decimal probability numbers, as "odds" and 
frequency expressions are more easily understood (Gigerenzer and Edwards 2003; Leclerc and Joslyn 2012; Henrich et al. 2015). We did not carry estimation of hazard all the way on to estimation of risk, so there was no quantification of how much risk could be reduced by various mitigation options. Pyroclastic flows are so lethal that vulnerabilities would have been nearly $100 \%$ and without evacuation, exposure would have been $100 \%$ too. Discussion moved quickly to plans for evacuations should an eruption become imminent.

We did prepare one update to this tree, on June 10, but by that time evacuation of Clark Air Base and nearby areas was already well underway and the new probabilities - much higher of course-were effectively moot.

In neither tree did we estimate uncertainty of our probability estimates, but in briefings about the first tree, we did indicate that uncertainty was at least plus or minus one order of magnitude. Simply using probabilities already indicated uncertainty about what would transpire. Indeed, in every episode of volcanic unrest there is a range of possible outcomes, including the null event of "no eruption." Use of probabilities, frequencies, or odds (especially, when combined with alert levels) allows scientists to bypass the as-yet unreachable goal of making very specific deterministic predictions of what will occur. Yes, officials and the news media will ask for such predictions, but we believe that it is scientifically more correct and educationally more useful to indicate the range of possible scenarios and to discuss how the probabilities of each scenario can be estimated and can change. Interestingly, recent research by Leclerc and Joslyn (2015) found that including probabilities in frost forecasts increased recipients' willingness to accept false alarms.

\subsection{Recommendations for Evacuation}

In the Philippines, PHIVOLCS typically recommends that a certain radius around a volcano be declared a "permanent danger zone" and that residence in this zone be forbidden. Outside that zone, restrictions or measures such as evacuations are at the discretion of local government officials. As Pinatubo had not erupted in historical time, no permanent danger zone had been designated, nor had there been any resolutions within provincial or municipal governments about when and where evacuations might be ordered. The Director of PHIVOLCS, with blessing from the national Office of Civil Defense, took on the responsibility for recommending radii of evacuation, and the Philippine Army together with the Departments of Public Works and Social Welfare and Development implemented those recommendations. Although an early, limited evacuation (in early April) proved to be porous, later evacuations in June had the advantage of visible eruptions and were relatively smooth and effective.

Although the boundaries of hazard zones are naturally irregular, based on topography, Director Punongbayan and Director Dejoras decided that recommended evacuations would be circles with radii of 10 and $20 \mathrm{~km}$ (later, including 30 and $40 \mathrm{~km}$ ). Circles drawn around the outer boundaries of the mapped hazard inevitably include some areas of relative high ground and safety, but it was judged to be simpler and more effective to base evacuations on simple circles rather than on the boundaries of hazard maps that some might not understand. Details are given in Tayag et al. (1996).

\subsection{Personal Communications}

Most of our communications with officials were of the formal types listed above-briefings, alert levels, hazard map, a probability tree, and recommended radii of evacuation. However, we found that informal, personal communications were sometimes just as effective as the formal ones, if not more effective. We already mentioned the gut-level emotional impact elicited by film clips of the young girl trapped and shivering in lahar deposit in Armero, Colombia.

A different and very effective form of personal communication was movement of scientists themselves to safer, fall-back positions-in the 
northwest, from Sitios (hamlets) of Tarao and Yamot to Barangay Poonbato, and on the east, from the center of Clark Air Base to the far eastern edge of the air base. The move was for our own safety, but we realized as we planned it that our action would be a strong message for others. As we hoped, local officials and residents took note and took our warnings more seriously thereafter.

Yet another form of personal communication was developing simple friendships and trust with those at risk. Several members of the PHIVOLCS team on the northwest side of Pinatubo, led by Julio Sabit, developed quick rapport with local residents. Eating together, drinking together, and sharing family histories and aspirations are wonderful ways to build the trust that becomes so essential when urgent warnings must be issued. A similar experience on the east side was generated accidentally on May 18 . The scientific team was exhausted and stressed, so we called a time-out for a BBQ, inviting Air Force officers to join. Over hot dogs and beer, the officers discovered to their surprise that we scientists were just normal people, with families of our own just like them. Probably, scientists had the same revelation about the military officers. Up until that time we had regarded each other with some puzzlement and caution; after the BBQ and beer, things lightened up and more trust was evident.

\section{Post-eruption Lahar Messages}

As soon as the climactic eruption occurred, it was obvious to scientists that the big threat in coming years would be from rain-induced lahars (Janda et al. 1996). We didn't know exactly what percentage of the fresh deposit would be washed into the lowlands in lahars (and in normal muddy streamflow) - estimates ranged from around 15\% to around $50 \%$. Even $15 \%$ of the new deposit would be enormous and would more than fill river channels; $50 \%$ would bury huge areas of farmland and towns under several meters of sediment. Even on the back of an envelope, scientists could see that these lahars would be bigger than anything they had ever seen or imagined. In contrast, most people at risk in the lowlands were blissfully oblivious to the lahar threat, grateful that they had survived the eruption. Even engineers and officials had a hard time envisioning the scale of the impending lahars.

Our messages for long-range and short-range lahar hazard included:

- There is an enormous amount of loose sand and pumice on the volcano that will be carried into the lowlands in coming months and years. (unquantified, no maps yet)

- Depending on assumptions, large areas including many towns may be buried, and here (on hazard maps) are the areas at high and lesser risk.

- If you build dikes to contain the sediment, most of these will fill and can breach if you don't build them big enough and strong enough.

- Some towns are not going to survive unscathed and may need to be sacrificed. People from those towns will need to be resettled in other places for the foreseeable future.

- Immediate warnings of lahars, e.g., "A (small/large) lahar has formed in the Sacobia River and will reach populated areas by (specified time)".

- Because lahars can go overbank and even breach protective dikes, populations still remaining at risk from these lahars should evacuate immediately.

In the late 1990s and in 2000-2001, two more messages were added:

- As the caldera lake fills, it will eventually overtop and may pose a severe lahar threat to Botolan (1998-2001).

- The threat of a breakout lahar still remains, because we didn't succeed to induce a rapid scouring/ breach of the loose material that forms a dam at the head of the Maraunot/Balin Baquero/Bucao river system (late 2001). 


\section{How Were Lahar Warnings Prepared and Presented?}

\subsection{Briefings and Video}

Briefings followed more or less the same pattern as during pre-eruption time, though more were held at the regional level than before the eruption. The Regional Disaster Coordinating Council (RDCC 3) assumed a greater role for lahars than it had before the eruption. More players were involved as well-with notably increased involvement by the Department of Public Works and Highways (DPWH); the Department of Social Welfare and Development (DSWD) (for emergency relief and more permanent resettlement of those displaced by lahars), and the new Mount Pinatubo Commission (a mechanism to coordinate funding and response, but relying heavily on DPWH, DSWD, and their contractors).

The Krafft video was still used occasionally, but was increasingly supplanted by live and taped coverage of actual Pinatubo lahars, beamed over broadcast TV. Scientists and at least two television networks also prepared their own video documentaries on Pinatubo lahars.

\subsection{Hazard Maps}

Everyone wanted to know if his or her town would be hit by lahars. Engineers and planners also needed to know the likely volumes of sediment that would move into the lowlands, for planning engineering structures and for debating the relative merits of trying to control the sediment versus simply relocating communities and letting the sediment flow.

The earliest hazard maps were prepared by PHIVOLCS (Punongbayan et al. 1991) by the Pinatubo Lahar Hazards Taskforce (PLHT, a cooperative effort of the Mines and Geosciences Bureau, Univ. of the Philippines, Univ. of Illinois at Chicago, and PHIVOLCS) (1991a, b), and by the Bureau of Soils and Water Management (1991). Revised maps were prepared by Pierson et al. (1992), PHIVOLCS (1992, 1994); and the Zambales Lahar Scientific Monitoring Group
(ZLSMG) (1993, 1994). ZLSMG was the successor to PLHT, comprised of university-based scientists including some PHIVOLCS scientists on study leave. By mutual agreement with PHIVOLCS, the ZLSMG handled most of the lahar study on the west side of Pinatubo (1992, 1994).

Although there were minor differences between the various maps, most of the maps were broadly similar and confusion between maps seemed not to be a serious problem. Greater confusion may have arisen over the use of lines rather than gradations. Lines are satisfying, but they inevitably give a sense of more certainty than actually exists. Lahar hazard in lowland areas is gradational, without sharp boundaries.

Later, PHIVOLCS was given an additional duty of certifying whether specific land parcels (e.g., those for new construction and bank loans) were "safe" or "unsafe" from lahar. In general, that meant simply locating the parcel of land on the published hazard map and certifying that it was inside or outside hazard zones. Though unstated, delineation of "safe" zones implies a choice of how low a hazard must be in order to call the zone safe. Everything was changing too fast for us to identify an "X-year floodplain" (one event in $\mathrm{X}$ years) but qualitatively, areas outside the hazard zones were judged to have "very or extremely low" probability of being inundated.

In general, the hazard maps served dual purposes of letting communities know their (qualitative) chances of being buried in the coming years, and letting engineers and planners design appropriate responses. To be sure, some mitigation measures were technically inadequate or even foolish (e.g., construction in 1992 of a new school in Sta. Barbara, Bacolor, which would soon be buried by more lahars), but these instances were not for want of good scientific information. More likely, they were driven by inattention, bureaucracy, politics, or profit.

\subsection{Short-Term, Immediate Lahar Warnings}

Four systems were used for lahar warnings. One, installed by DPWH with information fed by 
radio telemetry directly to the RDCC at Camp Olivas, San Fernando, used trip wires and rain gauges, placed near the foot of a pyroclastic fan and the head of the corresponding alluvial apron. They didn't last long, with the trip wires almost immediately tripped or stolen. A second, installed by PHIVOLCS and the USGS, used rain gauges high in the watershed and acoustic flow sensors (inexpensive, high-frequency exploration seismometers) lower on the pyroclastic fans but still above the alluvial fans. Data were telemetered to PVO where they were interpreted 24/7, and warnings were relayed to RDCC by telephone. Sometimes, PHIVOLCS observers would also report from watchpoints but these were not an essential part of PHIVOLCS' warnings. A third was direct observations of lahars by scientists from the ZLSMG, from watchpoints they manned in Dalanaoan, San Marcelino, and Malumboy, Botolan. Dalanaoan was midway down the alluvial fan of the Marella/Sto. Tomas River but still upstream from populated areas; Malumboy was well down the Bucao River but still $11 \mathrm{~km}$ upstream from Botolan. Results were sent in real-time to authorities. The fourth system also used direct observations of lahars, by policemen posted near the heads of several alluvial fans who then radioed reports to the RDCC.

Of the four systems, the PHIVOLCS and ZLSMG systems were scientifically superior, giving early and semi-quantitative information about both the scale and the travel speed of lahars, and the benefit of scientific interpretation. In retrospect, the PHIVOLCS system would have been better accepted if one of its scientists with good communication skills had spent more time at the RDCC. The police reports were less accurate than those from scientists but had the advantage of being simple and from familiar sources.

Because everyday thundershowers at Pinatubo are very localized, and neither the national meteorological service (PAGASA) nor the military had modern Doppler radar, meteorologists did not play as great a role at Pinatubo as they would today. However, they did make major contributions by warning of incoming typhoons that invariably generated lahars across the entire volcano.

In general, short-term lahar warnings did reach those at risk and saved many hundreds or even thousands of lives. Regrettably, they didn't manage to save all. We recall one instance in which PHIVOLCS had strong evidence for a lahar headed for Dolores, Mabalacat, and relayed its warning, but local officials deferred to the police system which did not sound the same alarm. Approximately 100 died as a result. In another instance, all systems warned of a major lahar headed for Bacolor town (by then, largely evacuated) and its satellite barangay, Cabalantian (not evacuated). Unfortunately, a large dike gave a false sense of security until it breached, and as many as 400 of those who did not evacuate perished.

\subsection{Probabilities of Lahars}

No effort was made to estimate either long-term or short-term probabilities of lahars. Most of the effort toward quantification was focused on estimating rates of sediment transport, both in lahars and in normal muddy streamflow.

\subsection{Personal Factors}

Ironically, the extra time afforded by lahars (relative to the pre-eruption period) created extra difficulties in communication. There were more end-users to be informed, and more scientists providing the information. In addition to the main players mentioned above, there were also engineering consultants from many countries. Scientists operating on limited (sometimes, shoestring) budgets anticipated the magnitude of the lahar hazard while engineers turned that information into lucrative contracts for sediment control and reconstruction.

There were, we must admit, some unfortunate clashes between scientists which contributed to the loss of scientific credibility. One area of seeming disagreement was on the efficacy of engineering works. Without going into more 
details, suffice it to say that both real and imagined differences got translated, on front pages and lead stories, into a personalized competition of scientific expertise. Scientists' credibility would have been higher, and the public served better, had these differences been resolved behind closed doors, and officials and the public been given consensus statements.

\section{Lessons to Remember}

Pinatubo was a pressure-cooker for scientists, demanding warnings well before full data sets could be collected. Many times, we had to suppress our scientific instinct to say, "Wait, let me collect more data." Information had to be given immediately. Timely communication of often-uncertain hazards information, pre- and post-eruption, saved thousands, perhaps even tens of thousands of lives.

Below, we list some lessons that we ourselves learned, and that we commend to readers:

- Start your communications immediately, preferably long before unrest begins. If that is not possible, then begin teaching about the volcano at least start as soon as unrest is noticed. Do NOT wait until you are sure about what the volcano will produce. Communicating well with all parties takes time, and volcanic crises can develop so quickly that there might not be enough time for communications if you wait until you know more.

- Make a checklist of what data must be gathered and analysed, and what information must be communicated to whom. It would be easy, in the rush and stress of unrest, to forget one thing or another. Do not think of this as an affront to your professional experience; rather, think of it as a pilot thinks of his or her checklist - as an extra safety measure.

- Even if the most immediate pre-eruption concern is for pyroclastic flows, don't forget to warn thoroughly of ash, in the air and on roofs. It can be life-threatening, even far from the volcano.
- Expect scepticism, especially where a volcano has long been dormant. This will make your communication job more difficult, but also more essential. Consider using a variety of approaches and tools (e.g., briefings, video, hazard maps, alert levels, probability trees, and personal touches) to reach both sceptics and converts. Different tools will be required for different audiences. Video is especially effective.

- Help officials to understand that every volcanic crisis has several possible outcomes, and that their relative likelihoods may change with time as new geologic and monitoring data are collected. Response plans should be flexible enough to account for several different scenarios.

- Don't be afraid to give warnings based on your best current data, even if you know those data are woefully inadequate. Some will argue that giving interpretations and warnings based on incomplete data may be worse than no warnings at all. We respectfully disagree, as we think it is scientists' societal duty to give the best warnings possible AT ALL STAGES of a crisis, even early on while uncertainties remain high. If Director Punongbayan had not been willing to risk his reputation and perhaps even his job to give warnings when he did, even though uncertainties remained high, we doubt that the evacuations would have been as successful as they were.

- Don't be afraid to include a "worst case scenario" among various scenarios, and put it in context by estimating relative probabilities of various scenarios. In the case of Pinatubo, we saw so much geologic evidence for VEI 6 eruptions and so little evidence for smaller eruptions that we put a high probability on the "worst-case" VEI 6 scenario.

- Similarly, don't be overly afraid of a false alarm. To be sure, officials and the public do have limited tolerance for false alarms (e.g., Atwood and Major 1998), but it is not zero, especially if you explain all of the possible scenarios and uncertainties. Use of alert levels and probability trees reduces the likelihood of 
false alarms. Consider also a social contract with officials and those at risk: If they want to be sure of warning, they must accept some risk of a false alarm.

- After an eruption that produces a large volume of ash and other pyroclastic debris, expect lahars over an extended period. With more time and players, communications will get more complicated, and may require new, proactive communication strategies to keep scientific advice in the forefront of further planning.

- Both before and after an eruption, strive for scientific coordination of all messages BEFORE they go to officials and the public.

- Recognize the importance of trust and personal connections between scientists, officials, and the news media. Sometimes, these are as important or more important than the formal warnings.

We close this chapter, proud of the successes but also conscious of the near-misses and failures. Communication of hazards information at Pinatubo was complicated, but also absolutely essential to mitigation of what would have otherwise been a much worse disaster.

\section{References}

Atwood LE, Major AM (1998) Exploring the 'cry wolf' hypothesis. Int J Mass Emerg Disasters 16(3):279-302

Barnes LR, Gruntfest EC, Hayden MH, Schultz DM, Benight C (2007) False alarms and close calls: a conceptual model of warning accuracy. Weather Forecast 22:1140-1147 and corrigendum 24:14521454

Bureau of Soils and Water Management (1991) Mudflow and siltation risk map (as of Oct 1991). Bureau of Soils and Water Management. Scale 1:200,000

Dow K, Cutter SL (1998) Crying wolf: repeat responses to hurricane evacuation orders. Coast Manag 26:237252. doi:10.1080/08920759809362356

Doyle EEH, McClure J, Johnston DM, Paton D (2014) Communicating likelihoods and probabilities in forecasts of volcanic eruptions. J Volcanol Geoth Res 272:1-15

Fearnley CJ (2013) Assigning a volcano alert level; negotiating uncertainty, risk, and complexity in decision making process. Environ Plan A 45:1891-1911
Fearnley CJ, McGuire W, Davies G, Twigg J (2012) Standardisation of the USGS volcano alert level system (VALS): analysis and ramifications. Bull Volc 74:2023-2036

Fiske RS (1984) Volcanologists, journalists, and the concerned local public: a tale of two crises in the eastern Caribbean. In: Explosive Volcanism: interception, evolution, and hazard. National Academy Press, Washington, DC, pp 170-176

Gigerenzer G, Edwards A (2003) Simple tools for understanding risks: from innumeracy to insight. $\mathrm{Br}$ Med J 327:741-744

Haynes K, Barclay J, Pidgeon N (2007) Volcanic hazard communication using maps: an evaluation of their effectiveness. Bull Volc 70:123-138

Henrich L, McClure J, Crozier M (2015) Effects of risk framing on earthquake risk perception: life-time frequencies enhance recognition of the risk. Int $\mathrm{J}$ Disaster Risk Reduct 13:145-150

Janda RJ, Daag AS, Delos Reyes PJ, Newhall CG, Pierson TC, Punongbayan RS, Rodolfo KS, Solidum RU, Umbal JV (1996) Assessment and response to lahar hazard around Mount Pinatubo, 1991-1993. In: Newhall CG, Punongbayan RS (eds) Fire and mud: eruptions and lahars of Mount Pinatubo, Philippines: Quezon City, Philippine Institute of Volcanology and Seismology, and Seattle, University of Washington Press, pp 107-139

LeClerc J, Joslyn S (2012) Odds ratio forecasts increase precautionary action for extreme weather events. Weather Clim Soc 4(4):263-270. doi:10.1175/ WCAS-D-12-00013.1

LeClerc J, Joslyn S (2015) The cry wolf effect and weather-related decision making. Risk Anal 35:385395

Leone F, Lesales T (2009) The interest of cartography for a better perception and management of volcanic risk: from scientific to social representations: the case of Mt. Pelée volcano, Martinique (Lesser Antilles). J Volcanol Geoth Res 186:186-194

Newhall CG, Hoblitt RP (2002) Constructing event trees for volcanic crises. Bull Volc 64:3-20

Newhall CG, Pallister JS (2015) Using multiple data sets to populate probabilistic volcanic event trees. In: Papale P (volume ed) Volcanic hazards, risks, and disasters, v. 2 of Hazards, disaster \& risks series. Elsevier, pp 202-232

Philippine Institute of Volcanology and Seismology (1992) Pinatubo Volcanic Lahar Hazards Map, as of August 1992. Prepared by PHIVOLCS; produced by National Economic Development Authority, NEDA. Scale 1:200,000 (updated after each major lahar)

Philippine Institute of Volcanology and Seismology (1994) Pinatubo Volcanic and Flood Hazards Map, as of December 1994. Prepared by PHIVOLCS; produced by National Economic Development Authority, NEDA. Scale 1:200,000

Pierson TC, Janda RJ, Umbal JV, Daag AS (1992) Immediate and long-term hazards from lahars and excess sedimentation in rivers draining Mt. Pinatubo, 
Philippines. US Geological Survey, Water-Resources Investigations Report 92-4039, 35 pp (see Plate 1)

Pinatubo Lahar Hazards Taskforce (PLHT; compilers, Paladio ML, Umbal JV) (1991a) Lahar hazard map of the Bucao River system, Pinatubo Volcano, Luzon, Philippines (as of October 11, 1991). Scale 1:50,000

Pinatubo Lahar Hazards Taskforce (PLHT; compilers, Umbal JV, Rodolfo KS) (1991b) Lahar hazard map of the Sto. Tomas River system, Pinatubo Volcano, Luzon, Philippines (as of August 23, 1991). Scale 1:50,000

Punongbayan RS, Besana GM, Daligdig JA, Torres RC, Daag AS, Rimando RE (1991) Mudflow Hazard Map, as of 01 October 1991. PHIVOLCS, printed and published by the National Mapping and Resource Inventory Authority, NAMRIA. Scale 1:100,000

Punongbayan RS, Bautista MLP, Harlow DH, Newhall CG, Hoblitt RP (1996) Pre-eruption hazard assessments and warnings. In: Newhall CG, Punongbayan RS (eds) Fire and mud: eruptions and lahars of Mount Pinatubo, Philippines: Quezon City, Philippine Institute of Volcanology and Seismology, and Seattle, University of Washington Press, pp 67-85

Open Access This chapter is licensed under the terms of the Creative Commons Attribution 4.0 International License (http://creativecommons.org/licenses/by/4.0/), which permits use, sharing, adaptation, distribution and reproduction in any medium or format, as long as you give appropriate credit to the original author(s) and the source, provide a link to the Creative Commons license and indicate if changes were made.
Tayag J, Insauriga S, Ringor A, Belo M (1996) People's response to eruption warning: The Pinatubo experience, 1991-92. In: Newhall CG, Punongbayan RS (eds) Fire and mud: eruptions and lahars of Mount Pinatubo, Philippines: Quezon City, Philippine Institute of Volcanology and Seismology, and Seattle, University of Washington Press, pp 87-106

Winson AEG, Costa F, Newhall CG, Woo G (2014) An analysis of the issuance of volcanic alert levels during volcanic crises. J Appl Volcanol 3(1):1-12

Zambales Lahar Scientific Monitoring Group (ZLSMG; compilers Alonso RA, Rodolfo KS, Remotigue CT, Umbal JV, Jalique-Calamanan V) (1994) Lahar Hazard Map of Western Mount Pinatubo, Zambales Province (as of July 1, 1994, revised from Pinatubo Lahar Hazards Taskforce, 1991, and ZLSMG maps of 1 July 1993, 21 September 1993, 8 October 1993,for Sto. Tomas and Bucao Rivers). Scale 1:50,000

Zambales Lahar Scientific Monitoring Group (ZLSMG; compilers Alonso RA, Rodolfo KS, Remotigue CT) (1993) Lahar Hazard Map of the Santo Tomas-Pamatawan Plain, Southern Zambales Province, as of September 1, 1993). Scale 1:50,000

The images or other third party material in this chapter are included in the chapter's Creative Commons license, unless indicated otherwise in a credit line to the material. If material is not included in the chapter's Creative Commons license and your intended use is not permitted by statutory regulation or exceeds the permitted use, you will need to obtain permission directly from the copyright holder. 